\title{
NEO-LIBERALISM AND THE PATHOLOGISING OF PUBLIC ISSUES: THE DISPLACEMENT OF FEMINIST SERVICE MODELS IN DOMESTIC VIOLENCE SUPPORT SERVICES.
}

Word length: 3,829 (excluding references)

\author{
Author \\ Associate Professor John McDonald \\ School of Behavioural and Social Sciences and Humanities \\ Centre for Health Research and Practice \\ University of Ballarat \\ Mt. Helen Campus \\ PO Box 663 \\ Ballarat, Victoria, 3353 \\ Phone (03) 53279818 \\ Fax (03) 53279840 \\ Email j.mcdonald@ballarat.edu.au
}

John McDonald (PhD) is Director of the Centre for Health Research and Practice at the University of Ballarat. His research interests include evidence-based practice and evaluation of social services. 


\title{
NEO-LIBERALISM AND THE PATHOLOGISING OF PUBLIC ISSUES: THE DISPLACEMENT OF FEMINIST SERVICE MODELS IN DOMESTIC VIOLENCE SUPPORT SERVICES.
}

\begin{abstract}
Using domestic violence support services as a case study, this paper examines how the ascendancy of neo-liberalism has individualised and pathologised public issues. Four perspectives are identified that have been influential in understanding the causes of domestic violence, determining responses to it, and measuring the effectiveness of support services. These four perspectives may be categorised as the: victim blaming, social movement, empowerment, and pathologising perspectives. From analysing the standard outcome measures currently used for government-funded accommodation programs, the author contends that the pathologising perspective dominates. This is partly attributable to the inherent methodological and ethical issues in evaluating programs of this nature. However, it is primarily driven by the ascendancy of a neo-liberal, managerialist ideology that has depoliticised and clinicalised domestic violence. This has effectively silenced structural analyses of domestic violence and displaced feminist service models.
\end{abstract}

Keywords: domestic violence, refuges, outcomes measurement, neo-liberalism.

\section{INTRODUCTION}

Feminists were instrumental in the development of services to support women and children escaping violence. From the first women's refuge in Australia, founded by a group of feminists in 1974, the women's refuge movement has continued to play a major role in 
the direct service provision, lobbying and advocacy (Murray 2002; Weeks and Gilmour 1996). In achieving these ends, the movement has used 'non-hierarchical methods of organisation such as collective management to avoid replicating oppressive hierarchical structures’ (Laing 2000a, p. 3). From these early efforts, there have been significant achievements in addressing domestic violence in Australia over the last two decades (Nancarrow and Struthers 1995; Laing 2000a). Private violence has become a public issue. Key improvements include legislative changes, task force investigations, the creation of domestic violence units within police forces, and funding for refuges, community education, counselling, and rehabilitation programs.

Nevertheless, domestic violence remains a major problem. In 2002-03, over 408,000 people in Australia were estimated to be victims of domestic violence. Of these, eightyseven percent are women (Partnerships Against Domestic Violence and Access Economics 2004). The governments' primary response to this is the Partnerships Against Domestic Violence (PADV) Program. In November 1997, the Heads of Government endorsed PADV, which is a joint initiative of the Commonwealth, States and Territories to address priority areas of domestic violence. Over the first three years, a total of twenty-five million dollars was spent, and a further \$25 million has been committed for the second triennium until June 2005 (Partnerships Against Domestic Violence 2003). Key projects have been funded in the following areas:

- assisting children and young people who have experienced or witnessed domestic violence;

- $\quad$ working with perpetrators and victims to prevent and reduce family violence;

- $\quad$ reforming legislation and improving responses to protect people at risk;

- community education;

- researching and sharing information about good practice, 
- $\quad$ establishing the Australian Domestic and Family Violence Clearinghouse; and

- overcoming barriers for people in regional Australia.

Accommodation services for people who are homeless or at risk of being homeless, including women and children escaping domestic violence, are primarily provided through the Supported Accommodation Assistance Program (SAAP), established in 1985. During 2002-03, funding was provided for 1,282 agencies across Australia. The main reason people use SAAP services is domestic violence, reported in twenty-two percent of support periods (Australian Institute of Health and Welfare 2003). Anonymous case management data about each client is collected and reported in the SAAP National Data Collection.

This paper commences by proposing four major perspectives on domestic violence, and the typical outcome measures associated with each perspective. The performance measures used for the SAAP are then interpreted in this light. Methodological and ethical issues in outcome measurement are then considered. The argument presented here is that these measures reflect a broader policy shift that has de-politicised and clinicalised domestic violence, and displaced feminist ideologies and models of practice that originally underpinned women's refuges.

\section{FOUR PERSPECTIVES ON DOMESTIC VIOLENCE}

Different theories have been advanced to explain the occurrence of domestic or family violence. For example, Dwyer, Smokowski, Bricout and Wodarski (1995) identify three general classifications: individual models (psychological), sociological models (socio-psychological), or socio-structural models (feminist). A theoretical framework such as this offers an understanding of the risk factors or causes of violence. However, for the purposes of this paper, this framework this does not readily reflect either the practice base or the model of service provision. Only when these factors are incorporated into an 
explanatory framework, can we start to analyse both the intended objectives of a support service and the effectiveness of that support.

This paper proposes four perspectives on domestic violence. These perspectives represent competing approaches to understanding the causes of domestic violence and determining appropriate responses to it. For our purposes, they also tell us how to gauge the success of the responses; in other words, each perspective will prescribe certain outcome indicators or measures of success of the intervention. The four perspectives are briefly outlined below.

Victim Blaming. This perspective places responsibility for domestic violence on the victim (typically the female partner). This approach commences from the assumption that the female plays the pivotal role in sustaining family life. Disjoined families are thought to be aberrant, and when they occur it is primarily due to the woman's failure in some capacity. For instance, Allen’s historical research concluded that: 'The bedrock of most habitual wife-bashing was the man's view that the woman had been insufficiently obedient, subordinate and attentive to his needs and desires' (1982, p. 4). Nancarrow and Struthers (1995, p. 44) argue that it is still common for women to be blamed for the violence, as is evidenced in myths such as 'women provoke their husbands' and 'women seek out violent men.' From this perspective, domestic violence is largely a private, hidden matter. Interventions, such as they are, would typically entail 'counselling' the deficient victim, and be directed at re-uniting the family. Thus, the key outcome measure is the victim's return to the perpetrator or the intactness of the family.

Social Movement. This perspective sees domestic violence as arising from, and sanctioned by, patriarchal structures of gender domination and power. In contrast to victim-blaming, the social movement perspective contends that domestic violence is a public, political problem. The social movement approach is rooted in feminist beliefs and 
action. Feminists advocate strategies that reverse the structural power imbalance: for example, legislative changes, and the establishment of service systems designed for and by women. From the social movement perspective, a successful intervention occurs when the woman decides to leave the perpetrator, or better still, when the perpetrator is forced to leave the family home. Other positive outcomes of these interventions are advances to women's economic, social, and political independence. For example, rather than domestic violence responses that 'construct(ing) women as victims who needs protection and seclusion', we should assert and enforce their human rights (Chung, Kennedy, O’Brien and Wendt 2000, p. 2). It is important to note that there are sharp disagreements within feminism regarding radical, socialist or liberal feminist ideologies and what these mean for practice (Egan and Hoatson 1999).

Empowerment. The empowerment perspective is based on the assumption that domestic violence arises when there is a power imbalance. The key difference between the empowerment and the social movement approach is that the former view casts violence as an interpersonal issue, and subscribes to the notion of the intergenerational cycle of violence. That is, that children and young people who experience domestic violence are destined to perpetrate and/or suffer violence in their adult lives (Laing 2000a; Laing 2000b). The solution, therefore, lies in personal empowerment for women in situations of domestic violence. Unlike the social movement approach, the empowerment perspective does not necessarily see that moving back to the perpetrator is a negative outcome. Support services aim to improve women's self-determination; to equip them with the skills to recognise and take control of domestic violence. The decision to stay with or return to the abuser is a legitimate option (Peled and Eisikovits 2000). The key measure of success is the woman's empowerment. Eisikovits, Buchbinder and Mor (1998) report on a group of women who exemplify the empowerment perspective. For these women, the 'turning 
point' is not the decision to leave the perpetrator; their turning point is actually the decision to continue to live with the perpetrator but to refuse to accept the violence.

Pathologising. The pathologising perspective sees domestic violence as a symptom of an unhealthy relationship or family. Violence erupts when family members are maladjusted or are not having their needs met. This approach adopts a therapeutic model to enable survivors to cope with their situation. Thus, upon entering refuges, women are assessed for treatment. Emphasis is 'placed on personal change: women are expected to “work on themselves” - often over fairly short periods of time' (Lupton 1994, p. 58). Case management is used to identify the client's needs and then coordinate services to meet those needs (see Dwyer et al., 1995). The client may be either the survivor or the perpetrator (the latter may be referred to group rehabilitation programs, for example). Success is measured in terms of achievement of the individual clinical goals of the client.

These four perspectives provide a context for understanding how governments prescribe, monitor and measure the work of agencies that are contracted to deliver domestic violence support services. The next section briefly examines some of the general methodological issues in measuring outcomes. The following section then critically analyses the standard performance measures used in the Supported Accommodation Assistance Program.

\section{METHODOLOGICAL AND ETHICAL ISSUES IN MEASURING OUTCOMES}

Research on, and the performance measurement of, domestic violence services encounters a range of methodological and ethical issues. A principal methodological problem with outcome measurement is the lack of definitive agreement about what constitutes family or domestic violence. Dwyer et al. (1995, p. 187) argue that 'reliably reporting and interpreting abuse stems from the distorting influence of culture and societal 
hierarchies on perceptions. Societal biases, norms and perceptions complicate effective assessment and intervention.' Schwartz (2000) has demonstrated how both the definition of family violence and the specific wording of survey questions can produce quite different results about the incidence of abuse.

Muller (1997) and Bowen, Brown and Gilchrist (2002) have identified several methodological issues with evaluating the effectiveness of programs for domestic violence perpetrators. The issues include: the definition and measurement of successful outcomes (given that male offenders under-report violence, that violence may shift from being physical to emotional, and that corroborating reports from the partner may not be obtainable); the research design (the lack of a comparison group, and the fact that those who complete treatment programs are less prone to re-assault than those who drop out); sample selection, attrition, the use of validated assessment tools, and the feasibility of longterm follow-up.

Abel (2000) and Jewkes (2002) conclude that there is little convincing evidence about the effectiveness of support services for abused women. A key reason for this is that it is only in the last few years that research attention has turned to program evaluation in social work. However, there are other reasons that pertain to the nature of domestic violence itself. First, services provided to women who are in crisis are open-ended and tailored to individual needs. Therefore, it is difficult to design an outcome study. Secondly, the imperative for service provision must take precedence over the requisites for experimental design. For obvious methodological and ethical reasons, control groups are rarely used. Thirdly, research tends to be based on convenience sampling, and there are usually high rates of attrition from the study sample. Follow-up is difficult with abused women; for safety reasons they may not leave a forwarding address, and contacting women who have returned to abusers may place them in additional risk. All these factors limit the 
conclusiveness of the findings. Fourthly, there is a real lack of consistency regarding the performance indicators set up for support services and of dependent variables in research studies. Finally, Abel (2000) argues that research in this area has failed to explicitly state the theoretical frameworks of practice underpinning the support services. Because of this, it is difficult to assess the efficacy of the specific interventions and to draw generalisations. Careful attention to ethical issues and safety, together with researcher-practitioner collaborations, may offer a way forward in the evaluation of domestic violence programs (Laing 2003).

\section{CASE MANAGEMENT AND SAAP OUTCOME MEASURES}

In 1994-05, SAAP strategic directions included the introduction of a case management approach. The stages of case management are service entry and assessment for eligibility; assessment of needs; service planning; direct service provision; coordination, monitoring and review of services; exit planning and case closure. The aim of this approach is to assist homeless people to achieve the maximum degree of independence, and become reintegrated into mainstream society (Chung et al. 2000, p. 20).

The National Evaluation of the Supported Accommodation Assistance Program (SAAP 111) (Department of Family and Community Services 1999) reported on progress and achievements of the operational aims of SAAP. The first aim is achieving a client outcome orientation through implementing a case management approach which includes the development of assessment and referral mechanisms. The need to develop measures of client outcomes was identified as an area for research, though the difficulty of developing appropriate performance indicators given the complexity and range of problems experienced by SAAP clients was noted. The National Evaluation reported that 'There does appear to have been a shift in emphasis from a focus on the type of support provided 
to individuals to expanding the nature of the outcomes of that support. Integral to this shift has been an active involvement of clients in defining their needs and the drawing up of action plans’ (Department of Family and Community Services 1999, p. 82).

SAAP-funded agencies use a standardised 'client form' to assess the needs of, and record the services provided to, individual clients escaping domestic violence. The form includes demographic questions, reasons for seeking assistance, sources of income support, type of housing and living arrangements before and after the support period, and the identified need for and provision of some 34 different types of support services. These services range from accommodation and income through to psychological services, family planning, meals, advocacy and assistance with legal issues.

The National Evaluation (Department of Family and Community Services 1999, pp. 86-87) leaves little doubt that case management was used as a government strategy to drive out prevailing models of service delivery and to call into question existing policies and practices: 'Fundamentally, case management has changed the face of SAAP agencies from being insular and largely unaccountable...Case management has started to have a profound effect on SAAP services and systems. It has begun to push the boundaries of conventional notions of service provision.' The introduction of case management and use of the client form thus enables much tighter specification of service targets and measurement of service outcomes. While performance measurement is not inherently unwelcome, its methodology and impact contributes to the individualisation of domestic violence.

Managerialism, the processes whereby public sector managers have, in the interests of greater efficiency, asserted their claims to control the provision of publicly-funded services, subordinates other forms of knowledge and power (Clarke, Gewirtz and McLaughlin 2000). It changes the way in which professionals within funded organisations 
are expected to think and behave. Within the service system, organisations have become more 'contractual, competitive and calculative' (2000, p. 9). SAAP-funded agencies have experienced such changes since the mid-1990s.

Feminist theories based on ideas of patriarchal dominance now hold little sway in government policy. This is reflected in a recent PADV meta-evaluation which explicitly discounts the value of 'early feminist' theories of domestic violence, and promotes a 'holistic, integrated approach'. The message is clear: funded agencies should accept the 'emerging agreement between policy advisors and practitioners' that this approach is most likely to be successful. Otherwise, 'it is possible for funded agencies to run programs counter to departmental and/or government policy or to fail to fully meet their own purpose and objectives’ (Partnerships Against Domestic Violence 2003, p. 9).

Egan and Hoatson (1999) argue that economic rationalism - which individualises problems - is antithetical to feminist ideologies, which emphasise structural solutions to public issues such as domestic violence. Their research showed that the government's imperative for high outputs (as measured by the number of women who receive a service) compromises an agency's capacity to meet the complex needs of women escaping violence. These needs often require intensive work over extended periods. However, the quality of the work and the outcomes for the women are subordinated to managerialist formulae concerned with unit costs and throughput. Thus, the problem is not simply one of underdeveloped data information systems or unsophisticated methodologies for evaluating program effectiveness in domestic violence. At the heart of the problem is the structuring of a competitive market of human services that suppresses the social change agenda of agencies such as government-funded feminist organisations. Egan and Hoatson (1999, p. 408) argue that: 
Central to feminist philosophy has been the commitment to link the personal to the political with services using their knowledge from their own service provision to build social action and community education programs to fight for structural change. ... Reliant on government funding, feminist services have to conform with government agendas which stem from an ideology which individualises problems. ... greater priority is being given to counselling methods where community problems are individualised and can be more easily evaluated in terms of output measures.

The increasing reliance by refuges on government funding and the co-option of refuges by larger, mainstream agencies has come at some cost to feminist ideology and models of practice (Srinivasan and Davis 1991).

Similar consequences have occurred in the United States of America, where the big increase in funding for women's shelters in the mid 1970s came at some cost to feminist principles. The expansion of shelters led to a professionalisation of the field by psychomedical 'experts' (Dobash and Dobash 1987). This led to a redefinition of the problem as the individual women and her relationships. Thus, upon entering shelters, women are assessed for treatment. The introduction of contractualism and competitive tendering has generated greater political control over service delivery. This, combined with the 'general political backlash against feminism ... has resulted in the renewed dominance of individualising and gender-neutral explanations of the problem’ (Lupton 1994, p. 72).

The use of outcome measures may appear to be largely a technical/administrative matter. In reality, this production-based model of service delivery (Meagher 2002) transposes values from a rationalistic, market-oriented world into the delivery of welfare services. As funding agreements are tied to direct service provision, the political voice of the community services sector is silenced. The community sector agencies 'increasingly 
represent the state (to the community) rather than represent the community (to the state)' (Kerr and Savelsberg 2001, p. 22). Moreover, the pitfalls in attempting to impose quantifiable outputs of programs onto services that value things such as social change has been widely debated (see, for example, Lindgren 2000). One of the major problems is the displacement of a program's goals and activities in order to comply with the requirements of the system of measurement.

\section{THE INDIVIDUALISATION AND VICTIMISATION OF DOMESTIC VIOLENCE}

Since the 1990s, at a state and federal level, a clear policy trend has been the depoliticisation of a feminist, gendered theory of violence against women to a more welfare-oriented, clinical theory of assistance to victims of violence (Hardiman 1998). This is seen in the Federal Domestic Violence Summits, domestic violence programs and Partnerships Against Domestic Violence that aim to keep families intact, respond to men’s health issues, and deliver programs for perpetrators. For women escaping domestic violence, safety has been of central importance to the success of refuge services. Content analysis of SAAP policy documents reveals that the concept of safety has become increasingly marginalised (Willis and Craft 2003). The idea of safety is largely missing from references to emergency accommodation.

Further to this, Chung et al. (2000) argue that the homelessness experienced by women escaping domestic violence reflects our society's failure to deal with this violence as a criminal offence. The expectation is that women should leave the family home to escape violence. Such a belief involves 'constructing women as victims who need protection and seclusion rather than as citizens with rights which can and should be asserted and reinforced' (Chung et al. 2000, p. 2). Other evidence of a shift away from feminist social change agendas is the downgrading of women's health policy units and the 
integration or mainstreaming of women's services (Wardle cited in Hardiman 1998). One early study documented how the mainstreaming of one refuge led to the subordination of feminist practice to the therapeutic ideology of the lead agency. Abused women were diagnosed, and classified as 'good' or ‘troublesome' depending on their cooperation with personal-change efforts (Ferraro 1983).

Structural explanations of violence and feminist models of service provision have been forced out in favour of a welfare orientation that focuses on meeting the individual needs of victims. Domestic violence has been reconstructed as a welfare problem, rather than a structural, gender issue.

\section{CONCLUSION}

The provision of government-funded domestic violence residential support services in Australia suggests a pathologising approach, which individualises the problem and strives to meet clients' therapeutic needs through case management. This is evident in the standard outcome measures currently used by SAAP funded services. The use of these measures is partly attributable to the inherent methodological and ethical issues in evaluating programs of this nature. However, it is primarily driven by a dominant managerialist ideology that has depoliticised and clinicalised domestic violence. When domestic violence is pathologised, it becomes redefined as an individual problem and deflects attention away from gendered power structures.

This is not to deny the need to provide services to individual women and children who are escaping domestic violence. Nor does it discount the benefits of an increased diversity of interventions (see, for example, The Women’s Services Network 2000; Sharon McCallum and Associates 2002). It is also acknowledged that pro-feminist rehabilitation models are being used to some effect in treating offenders (Bowen, Brown and Gilchrist 
2002). However, the renewed individualisation of the problem and the recasting of it as an issue of parenting and partner relationships (Department of Family and Community

Services 1999) is further evidence of the state's rejection of feminist theoretical analyses, and the weakening of women's services through defunding, amalgamation and mainstreaming (Weeks 1998).

At one level, the shift from input-based funding and the specification of outcome measures may be seen as merely a technical matter (Lindgren 2000). However, it is also the manifestation of a major shift towards free market economics and the ascendancy of managerialist practices through which governments have reformed their arrangements for funding human services (Australian Council of Social Services 1997). These policy shifts are part of a broader political struggle (Melville 1998) that have now effectively silenced structural analyses of domestic violence and displaced feminist service models.

\section{REFERENCES}

ABEL, E. (2000) 'Psychosocial treatments for battered women: A review of empirical research’, Research on Social Work Practice, Vol. 10, No. 1, pp. 55-78.

ALLEN, J. (1982) 'The invention of the pathological family: A historical study of family violence in NSW' in O'Donnell, C. and Craney, J. (eds.) Family Violence in Australia, Longman Cheshire, Melbourne.

AUSTRALIAN COUNCIL OF SOCIAL SERVICES (ACOSS) (1997) Keeping Sight of the Goal: The limits of contracts and competition in community services, Australian Council of Social Services, Sydney.

AUSTRALIAN INSTITUTE OF HEALTH AND WELFARE (2003) Homeless People in SAAP. SAAP National Data Collection Annual Report 2002-03. Australian Institute of Health and Welfare, Canberra.

BOWEN, E., BROWN, L. \& GILCHRIST, E. (2002) 'Evaluating probation based offender programs for domestic violence perpetrators: a pro-feminist approach’, The Howard Journal, Vol. 41, No. 3, pp. 221-236. 
CHUNG, D., KENNEDY, R., O’BRIEN, B., \&WENDT, S. (2000) Home Safe Home: The link between domestic and family violence and women's homelessness, Partnerships Against Domestic Violence, Canberra, Commonwealth of Australia,.

CLARKE, J., GEWIRTZ, S. \& MCLAUGHLIN, E. (2000) 'Reinventing the welfare state', in Clarke, J., Gewirtz, S. and McLaughlin, E. (eds.) New Managerialism, New Welfare?, Sage, London.

DEPARTMENT OF FAMILY AND COMMUNITY SERVICES (1999) National Evaluation of the Supported Accommodation Assistance Program (SAAP III), Commonwealth of Australia, Canberra.

DEPARTMENT OF FAMILY AND COMMUNITY SERVICES (1999) Working with Families Experiencing Domestic Violence, Commonwealth of Australia, Canberra.

DOBASH, R.E. \& DOBASH, R.P. (1987) 'The response of the British and American women's movement to violence against women' in Hanmer, J. and Maynard, M. (eds.) Women, Violence and Social Control, Macmillan Press, London, pp. 169-179.

DWYER, D., SMOKOWSKI, P., BRICOUT, J., \& WODARSKI, J. (1995) 'Domestic violence research: Theoretical and practice implications for social work', Clinical Social Work Journal, Vol. 23, No. 2, pp. 185-198.

EGAN, R., \& HOATSON, L. (1999) 'Desperate to survive: Contracting women's services in a region in Melbourne', Australian Feminist Studies, Vol. 14, No. 30, 405-415.

EISIKOVITS, Z., BUCHBINDER, E. \& MOR, M. (1998) 'What it was won't be any more: reaching the turning point in coping with intimate violence', Affilia Journal of Women and Social Work, Vol. 13, No. 4, pp. 411-424.

FERARO, J. (1983) 'Negotiating trouble in a battered women's shelter', Urban Life, Vol. 12, pp. 287-306.

HARDIMAN, A. (1998) 'The evolution of organisational responses and models in Victorian sexual assault services in the 1990s', Women Against Violence, Vol. 5, pp. 5056.

JEWKES, R. (2002) 'Preventing domestic violence', British Medical Journal, Vol. 324, No. 7332, pp. 253-255.

KERR, L. \& SAVELSBERG, H. (2001) 'The community service sector in the era of the market model: facilitators of social change or servants of the state?', Just Policy, Vol. 23, September, pp. 22-32.

LAING, L. (2000a) Progress, Trends and Challenges in Australian Responses to Domestic Violence, Issues Paper, Australian Domestic and Family Violence Clearinghouse, University of New South Wales, Sydney, NSW, Partnerships Against Domestic Violence. 
LAING, L. (2000b) Children, Young People and Domestic Violence, Issues Paper, Australian Domestic and Family Violence Clearinghouse, Canberra, Commonwealth of Australia, Partnerships Against Domestic Violence.

LAING, L. (2003) Research and Evaluation of Interventions with Women Affected by Domestic Violence. Australian Domestic and Family Violence Clearinghouse, Canberra, Commonwealth of Australia, Partnerships Against Domestic Violence.

LINDGREN, L. (2000) 'What does performance management do to non-profit values?', Evaluation News and Comment, Vol. 9, No. 1, pp. 5-10.

LUPTON, C. (1994) 'The British refuge movement: The survival of an ideal?’ in Lupton, C. \& Gillespie, T. (eds) Working with Violence, Macmillan, Hampshire.

MEAGHER, G. (2002) The Politics of Knowledge in Social Service Evaluation, UnitingCare Burnside Discussion Paper No. 1., UnitingCare Burnside, Parramatta, NSW.

MELVILLE, R. (1998) 'The slippery slide of women's refuge funding', Women Against Violence, Vol. 5, pp. 15-33.

MULLER, D. (1997) 'Aspects involved with evaluating family violence programs', Domestic Violence and Incest Resource Centre Newsletter, Vol. 1, pp. 11-17.

MURRAY, S. (2002) More Than a Refuge: Changing Responses to Domestic Violence, University of Western Australia Press, Crawley, Western Australia.

NANCARROW, H. \& STRUTHERS, K. (1995) 'The growth of domestic violence responses in Australia: A 'flash in the pan' or a sustainable program for change?' Social Alternatives, Vol. 14, No. 1, pp. 44-49.

PARTNERSHIPS AGAINST DOMESTIC VIOLENCE (2003) Information and Infrastructure: Improving Policy, Planning and Practice in Preventing and Responding to Domestic Violence. Phase 1 Meta-evaluation Report, Canberra, Office of the Status of Women, Australian Government.

PARTNERSHIPS AGAINST DOMESTIC VIOLENCE AND ACCESS ECONOMICS (2004) The Cost of Domestic Violence to the Australian Economy, Canberra, Office of the Status of Women, Australian Government.

PELED, E. AND EISIKOVITS, Z. (2000) 'Choice and empowerment for battered women who stay: Toward a constructivist model’, Social Work, Vol. 45, No. 1, pp. 9-26.

SCHWARTZ, M. (2000) 'Methodological issues in the use of survey data for measuring and characterizing violence against women', Violence Against Women, Vol. 6, No. 8, pp. 815-839.

SHARON MCCALLUM AND ASSOCIATES (2002) Outcome Evaluation of the Program to Measure and Compare the Effectiveness of a Prison-Referred and Community- 
Based Program for Indigenous Family Violence Offenders, Partnerships Against Domestic Violence, Office of Women's Policy, Northern Territory Government.

SRINIVASAN, M. AND DAVIS, L. (1991) 'A shelter: An organization like any other?', Affilia: Journal of Women and Social Work, Vol. 6, No. 1, pp. 38-58.

WEEKS, W. (1998) 'Sites of women's citizenship? Australian women specific services', Women Against Violence, Vol. 5, pp. 4-13.

WEEKS, W. \& GILMORE, K. (1996) 'How violence against women became an issue on the national policy agenda', in Dalton, T., Draper, M., Weeks, W. \& Wiseman, J. (eds.) Making Social Policy in Australia: An Introduction, Allen and Unwin, Sydney.

WILLIS, K. AND CRAFT, C. (2003) 'SAAP, safety and domestic violence: A content analysis', Just Policy, Vol. 31, pp. 24-30.

WOMEN'S SERVICES NETWORK (2000) Domestic Violence in Regional Australia. A literature review, A report for the Commonwealth Department of Transport and Regional Services, Partnerships Against Domestic Violence, Canberra, Commonwealth of Australia. 